\title{
References
}

Coleman, J. (1998) Social capital in the creation of human capital. American Journal of Sociology, 94 (suppl.), 95-120.

Durkheim, E. (1897) Suicide. Free Press (1951).

Hibell, B., Barbro, A., Bjarnason, T., et al (2003) The ESPAD Report 2003. Alcohol and Other Drug Use Among Students in 26 European Countries. Swedish Council for Information on Alcohol and Other Drugs (CAN) and the Pompidou Group at the Council of Europe.

Hirchi, T. (1969) Causes of Delinquency. University of California Press.

Kristjansson, A. L., James, J. E., Allegrante, J. P., et al (2010) Adolescent substance use, parental monitoring, and leisure-time activities: 12-year outcomes of primary prevention in Iceland. Preventive Medicine, 51, 168-171.

Rosenfield, P. L. (1992) The potential of transdisciplinary research for sustaining and extending linkages between the health and social sciences. Social Science and Medicine, 35, 1343-1357
Saxe, L., Kadushin, C., Tighe, E., et al (2006) Community-based prevention programs in the war on drugs: findings from the 'Fighting back' demonstration. Journal of Drug Issues, 36, 263-293.

Sigfusdottir, I. D., Kristjansson, A. L., Thorlindsson, T., et al (2008) Trends in prevalence of substance use among Icelandic adolescents, 1995-2006. Substance Abuse Treatment Prevention and Policy, 3, 12

Sigfusdottir, I. D., Thorlindsson, T., Kristjansson, A. L., et al (2009) Substance use prevention for adolescents: the Icelandic model. Health Promotion International, 24, 16-25.

Thorlindsson, T., Sigfusdottir, I. D., Bernburg, J. G., et al (1998) Vímuefnaneysla ungs fólks: Umhverfi og aðstæður [Substance Use Among Young People.] Rannsóknarstofnun uppeldis-og menntamála.

Yarnell, J. W. G. (2007) Epidemiology and Prevention: A System-Based Approach. Oxford University Press.

\section{Mental healthcare in the Slovak Republic: current situation and future challenges}

\author{
Jozef Dragašek MD PhD ${ }^{1}$ and Alexander Nawka MD² \\ 11st Department of Psychiatry, Faculty of Medicine, University of P. J. Safarik, Košice, Slovak Republic, email jozef.dragasek@upjs.sk \\ ${ }^{2}$ Department of Psychiatry, 1st Faculty of Medicine, Charles University, Prague, Czech Republic
}

\begin{abstract}
- he Slovak Republic is a landlocked country in central Europe with a population of over 5 million. The Czech Republic and Austria lie to the west, Poland to the north, Ukraine to the east and Hungary to the south. The largest city is the capital, Bratislava; the second largest city is Košice. Slovakia is a member of the European Union, the United Nations, the Organisation for Economic Cooperation and Development (OECD) and the World Trade Organization, among other international organisations. The majority of the inhabitants of Slovakia are ethnically Slovak (85.8\%). Hungarians are the largest ethnic minority (9.5\%). With a gross domestic product (GDP) of $€ 63.3$ billion in 2009, Slovakia is classified as a middle-income country. In that year total health expenditure represented $6.7 \%$ of GDP (Pažitný, 2008), 34\% of which went on pharmaceuticals, the highest share among all OECD countries (World Health Organization, 2010).
\end{abstract}

\section{Prevalence of mental disorders}

Two epidemiological studies have recently been conducted to assess the prevalence of depressive and anxiety disorders in Slovakia - the EPID (Heretik et al, 2003) and EPIA (Novotný et al, 2006) surveys. According to the EPID survey, the 6-month prevalence rate of depression is $41 \%$ ( $13 \%$ major depression, $5 \%$ minor depression and $23 \%$ depressive symptoms only); and according to the EPIA survey, the 6-month prevalence of generalised anxiety disorder is $4 \%$.
The overall rates for first lifetime contact with mental health out-patient services for all mental disorders has been reported to be 1724.4 per 100000 inhabitants (NCZI, 2009). Almost $27 \%$ of treated mental disorders were classified as neurotic disorders; organic disorders were the second most commonly treated conditions in the out-patient setting (20.5\%), followed by affective disorders (17.5\%) and substance use disorders (12.7\%) in 2008 (NCZI, 2009).

\section{Policy and legislation}

Slovakia has no laws specific to mental healthcare and there is no monitoring of the quality of care. Several independent bodies monitor human rights in general and some nongovernmental organisations address the human rights of those with mental illness (Bražinová et al, 2008).

Slovakia ratified the main human rights instruments in 1992, shortly before the division of Czechoslovakia and the establishment of the Slovak Republic. Mental healthcare falls under the general system of healthcare and is regulated by general healthcare legislation, which reflects much of the international thinking about human rights. An antidiscrimination act, adopted in 2004, bans discrimination on the grounds of health status. The government adopted the Charter of Patients' Rights in 2001 and this has since been promoted through various non-governmental activities. The Charter defines all the rights and entitlements of patients within healthcare delivery as they are stipulated in other 
legally binding documents. The Slovak Public Defender of Rights, for instance, monitors the legality of official decisions that affect individuals and the Slovak National Centre for Human Rights is an independent human rights monitoring centre that provides information and assistance.

The act on healthcare specifies forms of out-patient and in-patient care (Bražinová et al, 2008). It has improved the protocols for informed consent, the right to information, choice of provider, access to documentation, right to dignity, confidentiality and refusal of care. The Healthcare Surveillance Authority was established in 2005; it supervises public health insurance and the overall delivery of healthcare services.

\section{Personnel}

The professionals involved in mental healthcare may be classified as follows:

O medical doctors - psychiatrists, child and adolescent psychiatrists

O nurses - general nurses with secondary education, nurses with a bachelor's degree and nurses with a specialisation ('nursing in psychiatry')

O other health professionals with a degree - psychologists, social workers, physiotherapists, 'pedagogues' in health establishments, etc.

O health workers without a degree.

In 2004 the Slovak Republic had 32 psychiatric nurses, 10 psychiatrists, 3 psychologists and 1 social worker per 100000 inhabitants (UZIS, 2006). The shortage of nurses, social workers and case managers sometimes results in patients having no one to coordinate comprehensive care packages for them.

\section{Service delivery}

Nationally, there are 26 psychiatric wards in general hospitals (including the psychiatric departments in university hospitals), with a total of 1744 beds. These beds are used for short-term acute hospitalisations. The length of stay is limited by the health insurance companies to around 21 days (NCZI, 2009). The comparatively large number of beds can be explained by the tradition of in-patient care in central Europe and because hospital psychiatric services sometimes have to compensate for the lack of social care and community services. Community-based services, such as case management, rehabilitation centres, sheltered housing and employment schemes, are few in number (Table 1) and in fact only one region (Michalovce) has a system of community-based mental healthcare (Nawka et al, 2008).

\section{Training in psychiatry and in allied professions}

On the basis that well-trained mental healthcare personnel are at the foundation of quality care, the Slovak Republic has made important reforms in the post-communist period (Vevera et al, 2008). The structure of the system where most psychiatric patients are treated in general hospitals is, however, mirrored in the training requirements.
Table 1 Mental health services in Slovakia (2006) (population 5.44 million)

$\begin{array}{lr}\text { Facility/service } & n \\ \text { Psychiatric out-patient clinics } & 201 \\ \text { Psychology out-patient clinics } & 179 \\ \text { Day clinics } & 14 \\ \text { Case management services } & 1 \\ \text { Rehabilitation centres } & 60 \text { places } \\ \text { Sheltered workshops } & 12 \text { places } \\ \text { Sheltered living services } & 1 \text { (8 beds total) } \\ \text { Psychiatric departments in general } & 26 \text { (1744 beds total) } \\ \quad \text { hospitals } & 5 \text { (1392 beds total) } \\ \text { Psychiatric hospitals } & 4 \text { (630 beds total) } \\ \text { Mental hospitals } & \end{array}$

Slovakia has three medical faculties that provide comprehensive courses in psychiatry: the Faculty of Medicine, Comenius University, in Bratislava; the Jesenius Faculty of Medicine, Comenius University, in Martin; and the Faculty of Medicine, University of P. J. Šafárik, in Košice. Postgraduate training is directed by the Ministry of Health and executed mainly by the Slovak Medical University and other accredited institutions. The postgraduate curriculum is in accordance with the Charter of the Union Européenne des Médecins Spécialistes (UEMS; European Union of Medical Specialists) for training in psychiatry; it includes a variety of psychiatric in-patient and out-patient services. There are also 2-year certified courses for specialisation in geriatric psychiatry, psychiatric sexology and substance misuse. Two of three existing medical faculties, in Bratislava and Košice, are able to grant PhDs in psychiatry.

Psychology as an independent bachelor and masters degree programme is delivered by faculties of philosophy. There are also three public faculties and one private faculty for healthcare and nursing and one medical university focusing mainly on training, as well as 24 secondary medical schools.

\section{Research and publications}

Research in Slovakia is mostly carried out at universities and institutions attached to the Academy of Sciences. The most important are psychiatric departments within medical schools (Bratislava, Košice and Martin) and the Slovak Medical University. Unfortunately, mental health research in Slovakia is fragmented and largely ad hoc in nature, financed from different resources (Veselý \& Ocvár, 2008). Most scientific research is in biological psychiatry (e.g. electrophysiology in schizophrenia and addiction), epidemiology (depressive and anxiety disorders, suicide), quality of life and psychopathology.

There are only two professional Slovak mental health journals in which researchers can publish their results, and neither is indexed in the ISI Web of Knowledge. Research findings are often published in conference brochures.

\section{Plans for future}

In recent years, Slovakia has achieved important results in the organisation of its mental health services, but there is still a lot to do in order to achieve sustainability. Developments will focus on the following areas (Nawka et al, 2008). 


\section{Prevention}

Primary, secondary and especially tertiary prevention had been largely neglected. There is now, though, promotion of social integration and employment of individuals with mental illness in their community. Special focus should be placed on the mental health needs of children, adolescents and the elderly.

\section{Adequate resources}

A system with adequate resources must be created to support better quality of care and more consumer-driven services. This should actually reduce overall spending on mental health.

\section{Community-based care}

Most chronic beds in psychiatric hospitals should be eliminated or transformed to social health beds. Specialised secure departments for the compulsory long-term treatment of nonvoluntary patients are planned in psychiatric hospitals.

\section{Integration}

Mental healthcare is due to be better integrated into general health and social services, as care shifts away from psychiatric hospitals to psychiatric departments in general hospitals.

\section{Local participation}

Local government must be involved in health promotion, and in the treatment, rehabilitation and integration of patients into the community and labour market.

\section{Training}

New curricula will be needed for the transformation to community mental healthcare, which will require both traditional and new categories of personnel: social workers, case managers, primary care physicians, self-help group workers, patient advocates and advocacy experts.

\section{References}

Bražinová, A., Baudiš, P., Háva, P., et al (2008) Mental health policies and legislation. In Mental Health Care Reform in the Czech and Slovak Republics, 1989 to the Present (eds R. M. Scheffler \& M. Potucek), pp. 81-112. Charles University Press.

Heretik, A., Sr, Heretik, A., Jr, Novotný, V., et al (2003) EPID - Epidemiológia depresií na Slovensku. [Epidemiology of Depression in Slovakia.] Psychoprof.

Nawka, P., Dragomirecká, E., Dzúrová, D., et al (2008) Organizational structures. In Mental Health Care Reform in the Czech and Slovak Republics, 1989 to the Present (eds R. M. Scheffler \& M. Potucek), pp. 113-141. Charles University Press.

NCZI (Národné Centrum Zdravotníckych Informácií; National Health Information Centre) (2009) Zdravotnícka Rocenka Za Rok 2008. [Health Yearbook Year 2008.] NCZI.

Novotný, V., Heretik, A., Sr, Heretik, A., Jr, et al (2006) EPIA - Epidemiológia Vybraných Uzkostných Porúch na Slovensku. [Epidemiology of Selected Anxiety Disorders in Slovakia.] Psychoprof.

Pažitný, P. (2008) Stanovisko HPI k Rozpoctu Zdravotníctva na Roky 2009-2011. [Health System Budget 2009-2911 from the Standpoint of the Health Policy Institute.] Available at http://www.hpi.sk/hpi/ sk/view/2213/stanovisko-hpi-k-rozpoctu-zdravotnictva-na-roky-20092011.html (accessed August 2010).

UZIS (Ústav Zdravotnických Informací a Statistiky; Institute of Health Information and Statistics) (2006) Trendy Vývoje Zdravotnických Dat $v$ SR a CR v Letech 1994-2004. [Trends in Evolution of Health Data in the SR and CR, 1994-2004.] UZIS.

Veselý, A. \& Ocvár, L. (2008) Research and evaluation. In Mental Health Care Reform in the Czech and Slovak Republics, 1989 to the Present (eds R. M. Scheffler \& M. Potucek), pp. 225-250. Charles University Press.

Vevera, J., Bražinová, A., Nemec, J., et al (2008) Human resources and training. In Mental Health Care Reform in the Czech and Slovak Republics, 1989 to the Present (eds R. M. Scheffler \& M. Potucek), pp. 197-223. Charles University Press.

World Health Organization (2010) Slovakia. Country cooperation strategy at a glance. Available at http://www.who.int/countryfocus/ cooperation_strategy/ccsbrief_svk_en.pdf

\section{Psychiatry in the USA: an overview}

\section{Carol A. Bernstein MD, ${ }^{1}$ Bruce Hershfield MD $^{2}$ and Deborah C. Cohen MBA ${ }^{3}$}

'President, American Psychiatric Association, Associate Professor of Psychiatry, New York University School of Medicine, USA, email carol.bernstein@nyumc.org; ${ }^{2}$ Assistant Professor, Johns Hopkins University School of Medicine, Baltimore, MA, USA; ${ }^{3}$ Senior Writer, American Psychiatric Association

\footnotetext{
-he USA has the world's largest economy and the highest per capita spending on healthcare, but it lags behind other countries on a number of key health measures. It ranks 23 rd in healthy life expectancy and 32nd in infant mortality (World Health Organization, 2009). In 2000, the World Health Organization ranked the US healthcare system as $1 \mathrm{st}$ in responsiveness, 37th in overall performance, and 72nd by overall level of health (among 191 member nations in the study).
}

\section{Mental health in the USA}

Approximately $25 \%$ of US adults have a diagnosable mental disorder in a given year and approximately $6 \%$ have a serious mental illness. Mental disorders are the leading cause of disability for people aged 15-44 years (National Institute of Mental Health, 2010).

About $11 \%$ of adults experience serious psychological distress, such as anxiety and mood disorders, that result in 